\title{
Megszabva Városi kormányzás másutt és itthon
}

\section{Cutting edge \\ The Hungarian city governance in a European context}

\author{
HORVÁTH M. TAMÁS
}

HORVÁTH M. Tamás: egyetemi tanár, Debreceni Egyetem, Állam- és Jogtudományi Kar, Pénzügyi Jog és Közmenedzsment Tanszék; MTA-DE Közszolgáltatási Kutatócsoport; horvath.m.tamas@law.unideb.hu

KULCSSZAVAK: városi kormányzás, hálózatosság, átalakulás - állami szerepek, közjogi önkormányzat

ABSZTRAKT: A helyi önkormányzatokat szokásos megközelítés szerint az állami területbeosztáshoz kötik. A feladatok ellátása ugyanakkor a városiasság különböző fokait feltételezi, tekintet nélkül adott település és környezete közigazgatási besorolásának milyenségére. Az állami területbeosztáshoz nem kötött városi kormányzás kötetlen formái mindig is „körbelengik” a merevebb hivatalszervezési struktúrákat. A jelenség ebben az értelemben manapság reneszánszát éli Európában és a fejlett világ többi részén. A hálózatos formák tapinthatóak az urbanizált helyek között és közösségeikben, de ezek mindig együtt élnek merevebb struktúrákkal is. Ilyen a hierarchikus állami szerepek érvényesülése, ami egyben veszélyeket hordoz a hálózatosságra. De mind az államigazgatás szokásos struktúrája, mind a hálózati rendszer potenciálisan kikezdi magát a helyi demokráciát is. A probléma feltárása érdekében a tanulmány analitikus és empirikus módszert alkalmaz, az utóbbit összehasonlító kérdőíves felmérések adatainak elemzése útján.

Tamás M. HORVÁTH: professor, Department of Financial Law and Public Management, Faculty of Law and Political Studies, University of Debrecen; MTA-DE Public Service Research Group; horvath.m.tamas@law.unideb.hu

KEYWORDS: urban governance, networking, state restructuring, public self-government

ABSTRACT: From the point of view of governance, especially economic-based networking is in the focus of this article. Public works emerged in direct or virtual networks in the world, external cooperation became crucial in some of the huge projects as in public transport and the development of techno-poles. Additionally, investments promoted cities overlapping administrative boundaries to be competitive at different, even international levels and giving them opportunities to influence the complex area of development and governance further on. In particular cases, functions are spread among a wide range of participants and territorial areas, stepping over geographical or administrative borders. This approach may mobilise many resources. Non-administrative instruments have become more widespread at any scale, neglecting spatial aspects. However,

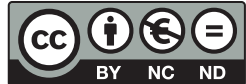


there is some risk of weakening democratic legitimacy, if the tradition of governance as such is not strong enough. New functional roles of the state may lead to centralism, threatening local democracy. The paper is partly an analytical one on a comparative basis, supplemented with results of cross-country empirical surveys.

The basic survey is based on structured personal interviews made by a professional public opinion poll institute in 2013-2014. The questionnaire was prepared by the project team. The basic population of the sample were mayors in Hungarian towns and cities. The sample is representative. The first group of questions referred to existing forms of economic networking. The second group of questions is about democratic legitimation and civil participation, because this issue is linked indirectly to the economic networking. In fact, in the community context, also interactive networking is emerging. This latter group of answers could be compared with similar surveys among French and German mayors. According to our findings the phenomenon of network governance exists in Hungary, however, the effect of this development seems to be more aggressive against classic legitimation in Hungary than it is in traditional democracies.

\section{Bevezetés}

A helyi önkormányzatokat szokásos megközelítés szerint az állami területbeosztáshoz kötik. Joggal, hiszen a demokratikus legitimáció a településeken és különböző megyei, regionális stb. szinteken választott testületek hatalmán alapul. A feladatok ellátása ugyanakkor a városiasság különböző fokait feltételezi, tekintet nélkül adott település és környezete közigazgatási besorolásának milyenségére. Az állami területbeosztáshoz nem kötött városi kormányzás kötetlen formái mindig is „körbelengik” a merevebb hivatalszervezési struktúrákat. A jelenség ebben az értelemben manapság reneszánszát éli Európában és a fejlett világ többi részén. Hogyan erősödött meg (nemzetközi összehasonlításban lásd Horváth, Józsa, Hoffman 2013), és milyen formái vannak? Hipotézisünk szerint a hálózatos formák tapinthatóak a mai urbanizált helyek között és közösségeikben, de ezek mindig együtt élnek hierarchikus struktúrákkal is. Az „arányok” közöttük időben változnak. A következőkben a téma analitikus elemzését adjuk, majd egy kérdőíves felmérés útján empirikus igazolást keresünk megállapításainkra.

\section{Elméleti keretek}

A nem területbeosztáshoz kötött városi önkormányzás formái és tartalmai különböző gyökerü elméletcsoportokban fogalmazódtak meg az ezredforduló után. Mindegyikre igaz azonban, hogy számtalan korábbi irányzatra épülnek rá. Közülük a hálózatos kormányzás az ernyőszerü teória, sokféle magyarázattal. A középszintü elméletek főbb köreit a helyi gazdaságfejlesztés (városi gazdaságösztönzés), a léptékelméletek újabb felfogásai, valamint a corporate governance önkormányzati alkalmazásai alkotják. Mindezen nézetek csoportjait tekintjük át vázlatosan. 


\section{Hálózatos kormányzási elméletek}

A hálózatos kormányzás (network governance) kutatása „többgenerációs” az elméletalkotás szempontjából (Howlett 2011; Sorensen, Torfing 2007). Tartalma több jelentéssel telített. A fogalom kiindulópontját közigazgatási értelemben a skandináv önkormányzati és társadalomszerveződési rendszerek jelentették (a téma mikroökonómiai megközelítéseiről lásd Hakanson 2010). Itt az önszerveződés mindig is fejlett volt, párosulva a gondoskodó közszektor gazdag és kiterjedt ellátórendszereinek kínálatával. Ebben a felállásban az önkormányzati formális állami-jogi intézmények komplementer társadalmi rendszerekkel vegyülnek, mely utóbbiak szintén intézményesülten, csakhogy nem éppen formáljogi értelemben szervesülnek. A polgár ekkor nemcsak piaci fogyasztója a közös javaknak és szolgáltatásoknak, hanem egyben cselekvő részes is a felhasználásban - miközben ezen szerepeit nem csupán választóként, „állampolgárként” gyakorolja.

A közigazgatásban mindez úgy csapódott le először az 1980-1990-es években, hogy a helyi és területi kormányzati intézmények szerepeit sok tekintetben felváltó kormányzási technikák és gyakorlatok kerültek előtérbe - mégpedig az emberek és közösségeik által közvetlenül ellátva. A kormányzás (governance), a maga tevékenységi formáival kezdte maga alá gyürni a kormányzat (government) klasszikus bürokratikus megoldásait (John 2001; Pierre, Peters 2000; a governance szakirodalmi irányzatait Bevir 2008 tekinti át). A valóságban persze a legfejlettebb országok is inkább egyfajta ígéretes együttműködési formát mutattak föl. Ezt a fejlődési formát az elméletek szerették egy szépreményü fejlődés kezdeti fázisaként fölmutatni (Stoker 2006; Sullivan, Skeltcher 2002). Utóbb kételyek is felmerültek, hiszen a lazább és formátlan hatalmi struktúrák nyilvánvalóan előbb-utóbb körülölelik a legitim szerveket. A rugalmas formák akármennyire is új perspektívát hordozóak, egyben önpusztítóak is (Stoker 2011) az önkormányzatokra nézve.

A hálózatos helyi kormányzástól aztán további lépcsőfokkal a városi, egészen pontosan városias (nem helyi!) kormányzáshoz jutunk, amelyik már nemcsak átível a merev közigazgatási határokon, hanem látványosan elszakad a területiség települési csomópontjaitól éppúgy, mint a területi lehatárolásoknak még oly informális formáitól is, mint például a várostérségek vagy agglomerációk.

További értelmezés szerint a hálózatosodás vertikálisan és horizontálisan is jellemző a nagyobb urbanizált önkormányzatokra (Collinge, Srbljanin 2003). Egyrészt illeszkednek az Európai Unió kormányzati rendszerébe, a nemzeti kormányaikon kívüli szálakon is. Erre példa a Régiók Bizottságán keresztüli kapcsolatok hálózata és a kiterjedt lobbitevékenység, amelyet az önkormányzatok folytatnak az uniós intézményekben. Horizontálisan pedig mellérendeltségi kapcsolataik vannak társulási-együttmüködési formákban, továbbá régiós keretek között. A hálózatok ezen túlmenően nemzeti kormányzati és helyi kormány- 
zati szinteken értelmezhetők (Marcussen, Torfing 2007), kiterjedésüket folytonosan minden szinten változtatni képes amőbákként.

A jelenséghez való eme kimondottan aktív hozzáállások alapvetésül szolgáltak egy univerzálisabb megközelítéshez, amely már az informatikai technológia elterjedésére épül. Az internet az utóbbi másfél évtizedben rohamos gyorsasággal részévé vált a mindennapoknak. A társadalom legkisebb egységéig lehatoló kapcsolatrendszer szerte a világon új formáit teremtette meg a modern közös érintkezési rendszereknek. A hálózat átformálja az interakciókat, befolyásolja a kulturális közegeket, bár egyben alá is rendelődik azoknak (Castells 2004).

A következmények és a fejlemények kétirányúak. Egyrészt a folyamat társadalomtechnológiai értelemben részévé válik a globalizáció általános gazdasági tendenciájának, egyben a mindennapi élet kereteit is alapvetően befolyásolva. Másfelől, az internetalapú társadalom sajátos technikái megjelennek a közösségi igazgatásban is. Az e-kormányzás az elektronikus rendszerek elötérbe állításával szembeszáll - mégpedig a lehető legközvetlenebbül - a papírés aktatologató hivatal hagyományával.

A különböző folyamatok egymásra találtak. A kormányzás weberi értelemben föl nem fogható formátlan megoldásai rokonságot mutatnak az internetalapú, ugyancsak formabontó, ám igen népszerü és hatékonyan terjedő eszköztárával. A hálózatos kormányzás ezért ennek a két különböző indíttatású és megjelenési formájú törekvésnek a találkozása. Különösen adaptívnak tűnnek az önkormányzati szinteken, ahol az érintkezés gyakorlata amúgy is hagyományosan közvetlenebb. Ugyanakkor mindig is kulcsfontosságú volt a horizontális és vertikális kapcsolatrendszerekbe való beágyazódás kormányzati-közigazgatási, területi-térségi, illetve társadalmi-közösségi értelemben egyaránt. Az elméletek szerették a folyamatot úgy beállítani, mint a formális intézményrendszerektől való eltávolodást. A folyamat előrehaladásával a megközelítés egyre inkább jogosnak mutatkozott. A jogi szabályozások ténylegesen legfeljebb követésre rendezkedhettek be. A már kiterjedt elektronikus nyilvánosságba becsatornázzák például az ügyintézési rendszereket, lehetővé téve a hiteles nyilatkozatok és joghatályos határozatok ilyen úton való közlését, a nyilvántartások kezelését és más hivatali vagy hivatali szerepet igénylő eljárásokat. Ezzel ez az elméletcsoport is igazodik azokhoz az áramlatokhoz, amelyek megkérdőjelezik a klasszikus hatalommegosztás rendszere szerinti állami szerepeket és tartalmakat, beleértve az önkormányzati struktúrákat.

Az Európai Unió politikaformáló közvéleménye - felismerve a hálózatos logika nemzeti-tagállami kormányokkal való ellensúlyának lehetőségét - szárnya alá vette az ebbe az irányba tartó törekvéseket (politikai és támogatási ösztönzésekkel, nem pedig jogszabályi vagy más jogi eszközökkel). A demokrácia építésének ezzel kimondottan nem csupán a klasszikus intézményi megoldásai mellett tették le a voksot. 


\section{Városi gazdaságösztönzés}

A kilencvenes évektől a fejlesztéspolitika tágabb értelmezéseként a helyi gazdaságfejlesztés (Mezei 2004; Péteri 2007) fogalma honosodott meg. E közkeletü kategória irodalma (Mezei 2007) jóval átfogóbb a kapcsolódó pusztán közigazgatási tartalmaknál, szélesebb összefüggésben a helyi gazdaságpolitika folytatását takarja. Magába foglalja többek között a vállalkozásösztönzést, a tőkebefektetést, a foglalkoztatásbővítést. Vagyis minden, a helyi erőforrásokhoz való hozzáadáson alapuló fejlesztést idesorolnak, ami közvetlenül vagy bizonyos, nem túl távoli áttételeken keresztül hatással lehet a lokális gazdasági viszonyok egészére (Péteri 2007). A továbbiakban a helyi gazdaságfejlesztést nevezzük témánk szempontjából kifejezőbben és némiképp szűkítően városi gazdaságösztönzésnek, mivel jellemzően városias szerepekről van szó infrastrukturális értelemben, tekintet nélkül az adott település jogállására. Másfelől inkább szakpolitika ez, mintsem pénzügyi fejlesztés csupán, ezért inkább a gazdaságösztönzés a megfelelő szókapcsolat.

A rendelkezési kapcsolatok alapján a konkrét kormányzási eszközök gyakorlatilag lokális és regionális politikai stratégiák mentén, azok által vezérelve kerülnek alkalmazásra. Érdekes ebben a körben a kínálat- és keresletoldali önkormányzati stratégiák (Faragó 1994; Mezei 2007) elkülönítése. Előbbi alapvetően a vállalkozások odatelepülését célozza különböző termelési tényezőik olcsóbbá tételével: telephelyi költségeik csökkentésével, kedvező munkaerő-kínálattal, adókedvezményekkel vagy más módon. A keresletoldali stratégiák viszont áttételes érdekeltséggel segítik a vállalkozói környezet gyarapodását: ipari parkok alapításával, képzési lehetőségek biztosításával, inkubátorházak létesítésével, vállalkozásbarát környezet megteremtésével. Azaz általában érdekeltek a helyi gazdaság eredményességének növelésében - talán áttételesebb érdekeltség mellett. A kínálatoldali stratégiák inkább köthetók a „naturális” helyi vagyongazdálkodáshoz. A keresletoldali stratégiák inkább állnak a politikai stratégiák uralma alatt. Jó gyakorlat mellett a közvagyon fölötti közvetlen rendelkezést a hosszú távú közös célok határozzák meg; illetve egy vagy több ciklus programelemeit is abba beágyazottan szolgálják jól a meghatározott hasznosítási döntések.

Szűkebb értelmezés szerint viszont csak a témakör egyetlen, értékirányultsággal felruházott részéről van értelme beszélni a helyi kormányzatok összefüggésében: az innovációösztönzésről, illetve a válsághatások enyhítéséről. Ezeket a lokalitással annyiban jellemezhetjük, hogy ezen értékek az elégséges hatékonyság szintjén csak akkor életképesek, ha a globális hálózatokba való egyszerü és többszintü bekapcsolódást biztosító infrastruktúra áll rendelkezésre, a hozzáférés széles körű biztosítása mellett. Az önkormányzati feladatok szokásos felfogásába inkább a szűkebb értelmezés illik manapság. Ugyanakkor tény, hogy a gazdaságfejlesztés általános összefüggésrendszeréből az így meghatározott szerepkört nehéz lenne kiszakítani. Az innovációösztönzés jobban kifejezi a helyi erőforrásokkal való gazdálkodás áttételes, a vagyon „forgatásában” és annak viszonyla- 
gosságában megnyilvánuló jellegzetességét. Ennek a tevékenységnek egyébként amolyan tükörképe a válságenyhítésben felvállalt szerepkör.

A gyakran szubvencionált helyi fejlesztési erőforráskoncentrációt célzó döntések terepe többé már nem az önkormányzat formális költségvetése. Hatása biztosan kritikus az olyan helyhatóságokban (kisközségekben), ahol a fejlesztés egyetlen kiegészítő forrása a korábbiakban innen származott. A beruházási tevékenységhez szükséges kompenzációs hozzájárulások ma már inkább az uniós támogatási rendszeren keresztül érkeznek. A címzett támogatások pedig korábban is egyedi központi (parlamenti) döntésen alapultak. A helyi érdekeltség ettől még nem szűnt meg, a döntésekben való részvétel formális keretei viszont kevésbé lesznek kitöltve. A városi gazdaságösztönzés tekintetében éppen az önkormányzattal való kapcsolati háló legális csatornái mosódnak el.

A gazdasági fejlődésnek van térbeli dimenziója. A helyi szereplők köre (Mezei 2007) széles: az önkormányzatokon és a kormányzati alárendeltségű területi szerveken kívül a vállalkozásoktól és vállalkozásfejlesztési intézményektől, a kamarákon, egyetemeken át a civil szereplőkig, szakszervezetekig terjed. Mindez a társaság térben is elhatárolható, amit a helyi gazdaságfejlesztés irodalmában a klaszter fogalmával írnak le (Lengyel, Deák 2002): a klaszter egy adott iparághoz tartozó cégek, intézmények telephelyeinek földrajzi „sűrűsödése". Tevékenységük helyi fejlesztési szempontból részben a beruházásokban, munkahelyteremtésben, tőkebefektetésben realizálódik (Péteri 2007). Érdekes, hogy a lokalitásnak van szerepe a globális gazdaság és az informatikai technológiai forradalom korában is. A térbeli sűrűsödés fókuszpontjai a nagyvárosok, térségei pedig a laza szerkezetű nagy kiterjedésű városias térségek, városrégiók. Tulajdonképpen minden településméretben kimutatható a gazdaságfejlesztés léte (Péteri 2007), legalább indirekt formában.

Az erőforrások felhasználásának módjait (Mezei 2007) a célokon kívül még az alkalmazás körülményei befolyásolják. Felmérések (Mezei 2004; Péteri 2007) tükrében a jellemző hasznosítási stratégiai összefüggések Magyarországon a következők:

- a helyi erőforrások kiaknázására épülő befektetésösztönzés,

- a munkahelyteremtés,

- nagyvállalkozásokkal kapcsolatos egyedi fejlesztéspolitika,

- kis- és középvállalkozások működési feltételeihez nyújtott támogatások,

- a kisebb településeken inkább közvetlenül adódó választási megfontolások (Péteri 2007),

- a helyiadó-politika alkalmazási gyakorlata a kivetés, kedvezmények alkalmazási köre stb. tekintetében.

Ugyanakkor mindez alapvetően termelési pólusok körüli erőtérben zajlik, amely folyton változik. Hagyományos településföldrajzi vagy közigazgatási területi kategóriákkal tehát nehezen írható le a jelenség tartalma. A fejlesztéspolitika gyakorlata már rég felismerte ezt a viszonyrendszert. A klaszterek termelési vagy szolgáltatási alapon szervezett gazdasági, pl. beszállítói együttműködések a térben. 
Előbbieknek megfelelően az Európai Unió területi és kohéziós politikájában is megjelent a városi térségekben, azok hálózataiban való gondolkodás és ösztönzés (vö. lisszaboni stratégia, lipcsei charta). Ehhez képest ma már inkább csökken a regionalizmusnak a területi politikában nemrég még korlátlanul érvényesülni látszó támogatáspolitikai eszméje.

A reálgazdasággal kapcsolatos feladatellátás általában véve sem tartozik az önkormányzatok alaptevékenységi körébe, csak bizonyos lépték fölött lehet erről áttételesen beszélni. Az Európai Unióban jó ideje úgy tűnt, hogy a közösségi szintről „még látható” tagállam alatti egységek, azaz nagyobb és szervesebben összetartozó térségek alkotják a gazdaságilag is értelmezhető térbeli fejlődés alapköveit. A régiókat nem volt szükséges minden országban közigazgatási, még kevésbé államszervezési alapelemként elfogadni, ennek hiányában tervezési és számbavételi egységként definiálták őket.

\section{Újabb léptékelméletek}

A területi közigazgatás szintjeinek lehatárolása véget nem érő viták forrása a különböző országokban. Közülük „európai polgárjogot” a régióvita nyert a kilencvenes évektől, bár számos európai ország fejlődésében a regionális önkormányzatiság nem jött létre. A szabadon felvállalható gazdaságösztönzési funkciók helyi letéteményesei ezért a még elégséges méretü kapacitásokkal rendelkező nagy önkormányzatok lettek, különösen a nagyvárosok. A regionalizmus összefüggésében a (nagy-)városi pozíció kisugárzó hatása nem jelentett többletet. Az újabb folyamatok tükrében azonban valamiféle merev területiséghez visszafordulni sem volt tanácsos, hiszen egyre inkább előtérbe kerülnek a pólusokkal jelezheto", természetes gazdasági kapcsolatokra épülő területi összefüggések.

Az Európai Unió kutatási keretprogramjaiban, valamint a kohéziós forrásokból támogatottan több kezdeményezés indult a kétezres évek folyamán a nagyvárosi és térségi feladatellátás szerepének és kereteinek meghatározására. De ekkor már nem annyira a minden áron való területbeosztási intézményesítéshez akartak eljutni. Hanem, látván az egyidejűleg jelen lévő ellenállásokat, onnan közelítettek, hogy a változó reális térkapcsolatok milyen gazdaságösztönző szerepet képesek közvetíteni. Például szolgálnak erre az ESPON-kutatások (lásd különösen ESPON 2006), amelyek több hullámban is vizsgálták az európai nagyvárostérségek lehatárolási kérdéseit. Az átfogó vizsgálatok elkülönítették egymástól a nagyvárosi morfológiai és a funkcionális térséglehatárolásokat - függetlenítve ezeket már kiinduláskor is a közigazgatási területszervezési viszonylatoktól: az urbanizációs centrum, illetve sokszor policentrikus pólusok szervező erejének hatásait, azok alakulását állították középpontba (METREX 2005). Ennek a térszervezés-politikának újabb fokozatát jelentik az Európai Területfejlesztési Alap (ERDF) URBAN közösségi kezdeményezésén belüli URBACT programok, melyek közül jelenleg az URBACT III van folyamatban. A 
várospólusok által kialakított térségek gazdasági és társadalmi funkciószervezése áll az együttműködés-szervezés középpontjában, azzal a feltevéssel és szándékkal, hogy az uniós politikák új megvalósítási hálózatát lehessen kiépíteni közösségi szinten.

A téma hazai közigazgatási kapcsolatainak összefüggéseire jól mutat rá a Tér és Társadalom 2008. évi tematikus száma (Pálné Kovács 2008a, 2008b), melyből alapvető következtetések adódnak a jövőre nézve. A városi pólusokra épülő területi fejlődés elve előbb-utóbb meghaladhatja a térségalapú regionális rendszerek koncepcióját. Ugyan már a régiók európai struktúrája is túllépett a decentralizált igazgatás hagyományos módján, a strukturális források felhasználásának rendje önmagában is ezt sugallja. A városi erőközpontok kisugárzásához rendelt közfeladat-ellátási módok és kapcsolatok hálózata elszakadni látszik az „átfedésmentes” formális adminisztráció hagyományától. Még véletlenül sem gondolnak a szereplők jogi intézményesítésére, hiszen ezzel a támogatni kívánt rugalmasságot és alkalmazkodóképességet veszélyeztetnék. Ebben haladja meg a póluslogika igazgatási értelemben a hetvenes évek metropoliszigazgatási kísérleteit, melyek éppen intézményesítettségük révén lettek elviselhetetlenek a kormányok számára. A nagyvárosok és környékeik együtt, önkormányzatként túl nagyok és erősek voltak. A mai felismerésekben döntő a „mozgásban levés”. Az európai várostérség-hálózatoknak például nagy szerepe van a globális gazdasági fejlödésben, a kohézióban, és a válságkezelésben is aktív szerepet játszanak. De korántsem ugyanazokkal az eszközökkel és nem is feltétlenül ugyanarra a térre kihatással, így kormányzási eszközeik is változnak. Nem épülhetnek tehát a szokásos hatáskör-telepítés és a rendelkezési jogosítványok elosztásának formális rendjére.

Éppen ezért kerül képbe a kormányzás fogalma. A városi kormányzás közvetettebb eszközei elhatárolhatóak az önkormányzat-centrikus területi igazgatási logikától (lásd a government és a governance fogalompárját). Hangsúlyozandó, hogy ezt a hálózatos eszközrendszert nem kell létrehozni, hiszen szervesen jelen lévő kapcsolatrendszerekről van szó. Éppen emiatt kiváló tárgya lehet adott esetben európai és más területi politikai ösztönzéseknek (Somlyódyné Pfeil 2011). Ebben az összefüggésben világos, hogy nemcsak a nagyvárosok (Homan, Howl, Tosics 2007) jönnek képbe, hanem velük összefüggésben vagy önálló célzott hálózatokként kisebb városok is környező térségeikkel (Somlyódyné Pfeil 2008).

Tulajdonképpen a nagyvárosszerepek már túlnőttek a lokális kormányzásigazgatás által szabott kereteken. A középszintek szerepeit térképző pontjaik és vonzási mezőik kapcsolatrendszere egészíti ki, amelyet nemcsak települések, hanem gazdasági, szolgáltatási és más struktúrák területi viszonylataival jellemezhetünk. Például a közlekedési vállalatok szolgáltatási tevékenysége kiterjed a környező települések egy részére is. Ha pedig a távolsági közösségi közlekedés rendszerét összekapcsoljuk a napi ingázással, akkor a térbeli hatás jóval nagyobb. Világos, hogy itt kormányzási elemekről beszélünk, például a menetrendek és tarifarendszerek összehangolása, avagy összehangolatlansága folytán. Az 
új motorvonatok rendszerbe állításánál a vonalak kijelölése, a járatritkítások, a szárnyvonalak bezárása az embereket húsbavágóan érinthetik, térségek ellátottsága, foglalkoztatottsági helyzete változhat meg. E helyzetek azonban területi illetékességeken belül vagy a meglévők között nem kezelhetők. A közszolgáltató vállalatok kétszeresen is a hálózatok elemei. Egyrészt gyakran nagy európai szakmai szolgáltatók „leányai”, másrészt maguk is a terjeszkedés „gócpontjai", amikor szolgáltatási tevékenységüket más városok szolgáltatói társaságaiban szerzett részesedésekkel bővítik. A hálózatosság már önmagában is kizárja a területiség lehatároláson alapuló értelmezését. Adott esetben, államosítási tendenciák keretében, az állam veszi vissza a hálózatok kezelését.

Összességében tehát a városi kormányzás lehatárolhatatlanságához alkalmazott politikaformálások és eszközrendszerek tudatos kialakulásának korát éljük. A helyi rendelkezési jogok tekintetében ez nagyon érdekes következményekkel jár. Az alulintézményesítettség önmagában nem baj. Inkább a formális rendszereken átívelő kapcsolatrendszerek kezdetlegessége okoz gondot. Márpedig ez egy kritikus tömegen túl vagy válságos helyzetekben társadalmilag sokkos szituációkat, esetleg „félreintézményesülési” folyamatokat generál. Ugyanakkor a kapcsolatrendszerek nem bürokratikus formái társadalmi értelemben akkor eredményesek, ha világosak az alapstruktúrák egymást érintő vagy egymást keresztező határvonalai.

A kormányzás fogalmát ma már széles körben állítják szembe az intézményes kormányzattal (Józsa 2008; Stumpf 2008) és az állami területbeosztáshoz kötött igazgatással, legyen az államigazgatás vagy önkormányzati igazgatás, illetőleg összefüggésbe hozzák a hálózatos társadalomszervezési formák terjedésével (Marcussen, Torfing 2007; Sorensen, Torfing 2007). Ennek az irányzatnak a hatásai a városigazgatásban is jól érzékelhetőek (Tosics 2008).

\section{Önkormányzati corporate governance}

A társasági jog corporate governance (Dietrich 2011) fogalma a társasági jogi szemléleten alapul, amely a nagyvállalatok belső igazgatási viszonyainak szükségszerű szabályozását hangsúlyozza. Ez a szabályozás kifejezetten arra irányul, hogy a „felelős” tulajdonlásnak a részesedések iránti érdekeltségen túl legyen szakmai stratégiai szerepe is, de az operatív irányítás jogosítványait ne korlátozza. A felelős tulajdonlás régi gyökerekből (Herrigel 2007) táplálkozó, ugyanakkor újabb tartalmakkal telítődött fogalom. Modern alapjait a német társasági jogban fektették le, ahonnan a kétezres évek elején széles körben elterjedt.

A corporate governance a vállalati uralmi-irányítási viszonyok önazonosságot hangsúlyozó rendszere. A világgazdasági globalizációs folyamatok lokális/nemzeti hatásait különíti el, és kiemeli az ezen a szemléleti alapon nyugvó jogi intézményrendszert. A határokat nem ismerő tőkemozgásokat figyelembe véve tettek különbséget a jogi megoldásokban a részvényben való részesedés és 
a vállalkozásban való tevékeny részvétel között. Ez valójában kétfajta motivációt takar. A tulajdonos esetében megjelenik mindkét szempont, de az egyik kifejezetten a tőketulajdonlásban (having a share), míg a másik döntően a szaktevékenység vitelében (having a stake) lehet a gazdálkodás alapja (Ziegler 2000).

Az alapokat a 20. század első harmadára megerősödött ipari nagyvállalatok teremtették meg, mivel a termelési tevékenységgel összefüggésben jelentős kiterjedésű társadalmi és életmódközösségeket hoztak létre. Például a Siemens, a Philips vagy a nagy autógyárak a termelésszervezésük részeként lakótelepeket, szolgáltatásokat működtettek nagyszámú munkavállalóik és családtagjaik számára. Ennek meghatározó hatásai több emberöltőn keresztül megjelentek a vállalati székhelyül, telephelyül szolgáló városok, térségek infrastruktúrájában. Szociális téren a munkavállalói jogok érvényesítése, a szakszervezeti szerepek elismerése is része volt ennek a modellnek. Elsősorban a nagyvállalatok ipari termelési körére volt jellemző ez a szerveződés, a kereskedelemre, a bankszektorra kevésbé.

A huszadik század harmadik harmadában az egységesülő világgazdaság értékteremtési logikája azonban a tőke és más alapvető gazdasági erőforrások akadályoktól mentes, szabad áramlásán alapul. Befektetői szempontból ennek számos előnye van, azonban a közösségi hozadékok negatívan jelentkeznek a legfejlettebb országokban is. A tőke rugalmassága ugyanis nincs különösebben tekintettel arra tényre, hogy a munkaerő nehezebben és hosszabb távon mobilizálható, még akkor is, ha igyekeznek megkönnyíteni a mobilitást. Mindemellett a fejlett világ modelljei is eltérnek. Míg az amerikai gazdaságban a részvényesi érdekeltség dominál, a német vállalati struktúra inkább a tulajdonosi és dolgozói közvetlen részvételre épül.

A globális verseny egyértelműen a befektetési és banktőke szerepét helyezte előtérbe. A hagyomány miatt viszont nem meglepő, hogy erre a tulajdonos vagyoni érdekei védelmében - a corporate governance keretében - a felelös tulajdonlás felelevenítésével és megújításával válaszolt, ugyancsak a német gazdasági jog alapján. Az 1990-es években a német társasági jogba és joggyakorlatba olyan elemeket, intézményeket ültettek, amelyek lehetővé tették a vagyonnal kapcsolatos közvetlen tulajdonosi-rendelkezési érdekeltség megkülönböztetését a kizárólag részvényesi-részesedési érdekeltségtől. (Az alkalmazást kötelező üzleti „etikai” kódex foglalja magában - German corporate governance code 2010)

A közüzemi szektor több értelemben is részese volt a társasági korporatizációs folyamatnak. Egyrészt az itteni nagyvállalatokra is - mint termelő infrastrukturális szolgáltatásokat elóállítókra - igaz volt a fentiekben leírt társadalmi hatásokról szóló jellemzés. Elegendő a gázművek, az energiatermelés és -szállítás (korábban nem váltak el egymástól) vagy a nagyvárosi közlekedési vállalatok szervezési, juttatási hagyományaira utalni. Másfelől viszont a kormányzati szabályozási szerepek mindig is hatást gyakoroltak a versenygazdaság e területeire.

Az Európai Unió liberalizációs politikái jelentős mértékben éppen ezt a szektort célozták és érték el a kilencvenes évektől. A fejlett országokban is ki kellett nyitni a korlátozott társasági szabályozást e folyamat keretében és hatá- 
sára (Lorrain 2005; Wollman, Marcou 2010). A felelős tulajdonlásnak a szektorra való kiterjesztése ugyanakkor megkövetelte, hogy a kormányzati tulajdonosi minőséget a társasági jog intézményein belül fogalmazzák meg.

A corporate governance (ön-)kormányzati rész- vagy teljes tulajdonlású közüzemi infrastrukturális körben való alkalmazása a közszektor által alkalmazott eszközök körében jelentős változásokat hozott, olyan környezetben, ahol a közösségi tulajdon jelenléte és aránya jelentős maradt. A korábbi közüzemi vállalatokat „rendes” társasággá alakították ugyan, de az átvett modern korporatizációs megoldásokat a közszektorbeli szerepek érvényesíthetőségének játéktereként alkalmazták. A felelős tulajdonlás a közösségi felelősség érvényesíthetőségének formai keretévé vált.

Elsősorban a vállalatirányítás körében valósult meg mindez (Grossi 2007; Grossi, Reichard 2008; Grossi, Thomasson 2011), a vezető szervekben az önkormányzati képviselö-testületnek, tagjainak, vagy kinevezettjeinek révén tudja érvényesíteni akaratát. A kontinentális rendszereket nézve közvetlen képviselet valósul meg a résztulajdonlás jogán Németországban, Ausztriában, Svédországban és más, köztük kelet- és közép-európai országokban. A másik alapmodellben - például Franciaországban vagy Olaszországban - viszont összeférhetetlenség miatt az önkormányzati közvetlen delegálás tilos, ezért ott a választott képviseleti testület kinevezési jogot gyakorol részesedése arányában, vagy attól függetlenül többségi mértékben.

Az országcsoportok között különbség van a vállalati vezetőtestületek szintjeinek száma és feladataik megosztása között is. Németországban az operatív igazgatóság mellett felügyelőbizottság működik, amely stratégiai döntéseket hoz. A felügyelőbizottságban az önkormányzati képviselők mellett felerészben a munkavállalók képviselői vannak jelen. E testületekhez képest a közüzemi társaságok részvényesi közgyűlésének döntési szerepét szociológiailag nem tartják meghatározónak. Az ellenőrzési funkciót ugyanakkor nem a felügyelőbizottság, hanem az önkormányzat belső ellenőrzési egysége látja el, külső auditálás mellett.

Ebben az összefüggésben a másik modellt megtestesítő Olaszországban testületi értelemben a vezetés egyszintű. Az igazgatóság a végrehajtó és stratégiai felügyeleti funkciókat egyaránt ellátja. Tagjai szakemberek vagy nem hivatalban lévő (szak)politikusok. A közgyűlés és az auditáló testület elkülönülten müködik. Ebben a modellben, ha más eszközökkel is, a kormányzati szint befolyását szintén a társasági jog intézményei útján valósítja meg, meghaladva ily módon saját tradicionális közüzemi formáit. Meghaladja a szokásos önkormányzati igazgatás közjogi logikáját is, mivel az infrastrukturális szolgáltatások vállalati szervezése túllép a települési vagy területi határokon, a tőkemozgás pedig a tagállami, nemzetállami kereteken. Az állam és a társaságok közötti stratégiai és befektetési kapcsolatok hálózatosan, pontszerü elemek összefüggéseiben müködnek, azaz nem feltétlenül a területi lefedettség logikája mentén.

Az önkormányzati tulajdonosi érdekeltség társasági jogi megoldásokba történő korporatizációs beépítése a kiszerződési elv ellenében hat. A tulajdonos stratégiai érdekei ugyanis eltérőek lehetnek, és ezt a felelős tulajdonlás logikája 
inkább alátámasztja, mint gyengíti. Ráadásul már a társasággá alakítások révén megfelelnek a versenykövetelményeknek, melyeket az európai integráció liberalizációs politikái követelnek meg. Az ezredfordulótól az Európai Unió közszolgáltatásokra és általános gazdasági érdekeltségű szolgáltatásokra vonatkozó szabályai is kezdik respektálni a versenyeztetés korlátozását a százszázalékos vagy jelentős többségi köztulajdonú vállalkozások esetében.

\section{Az állami szerepek helye a hálózatosság alakulásában}

Az állam szerepei különbözőek a hálózatosodás folyamatában (vö. Somlyódyné Pfeil 2014 gondolatmenetével a kooperatív vonásokról).

Először is mindig jelen lévő abban az értelemben, hogy a helyi önkormányzatok, területi egységek mellérendeltségi kapcsolatait megfelelő intézmények útján elősegíti. A kontinentális lokális igazgatási rendszerek különböző, régóta működő formákat biztosítanak erre.

Másrészt a modern struktúrák lehetővé teszik az állami területbeosztáson túllépő hálózatosságot. Itt sem a kapcsolati pontok, sem a közöttük lévő viszonylatok nem feltétlenül igazodnak a helyhatósági rendszer elemi egységeihez vagy formális jogviszonyaihoz. A hálózatosság nem formális elemekből álló önkormányzatok hálózata, ezért az állami szabályozás, együttműködés nem is tudja úgy segíteni ezt a folyamatot, mint saját egységeinek horizontális kapcsolatrendszereit. A mi témánk alapvetően ez. Meg kell jegyezni azonban, hogy efféle viszonyok mindig is voltak és lesznek, legfeljebb az állami és önkormányzati szabályozások kevésbé vagy éppen jobban vesznek tudomást róluk. A formális intézmények az igazgatás, a jog, a gazdasági eszközök alkalmazásával ugyanakkor sokat tehetnek a hálózatosságért, ha ösztönöznek, vagy annak révén, ha egyszerüen nem tesznek semmit.

Mondhatnánk „hálózatoknak” a hierarchikus igazgatás rendszereit, a maguk vertikális és az azokat kiegészítő horizontális kapcsolataival. A hálózatosodás értelmében azonban ezek „álhálózatok”, mert hiányzik belőlük a gazdasági és társadalmi viszonyok változó alakulásához szükséges természetes spontaneitás és az ahhoz kapcsolódó formátlanság. Bizonyos feladatokat persze csak ezeken keresztül lehet ellátni, például a rendészeti tevékenység jelentős részben mindig ilyen. Különösen érdekes kérdés, ha a hierarchikus szervezetigazgatás konkurálni akar a mellérendeltség vagy éppenséggel a hálózatosság formáival; manapság erre is találunk példát.

Jelen tanulmányban e hálózatos formák változatainak alaptípusait és az azokhoz való közjogi viszonyulást tekintjük át az aktuális magyarországi rendszer empirikus vizsgálatával. Majd ezt összevetjük két tradicionálisan mintaértékü modellel (Hoffmann-Martinot, Wollmann 2006), a francia és a német rendszerekkel. 


\section{Az empirikus vizsgálat eredményei}

A kutatás keretében a magyar önkormányzatoknál empirikus munkát végeztünk. Városvezetőket kérdeztünk meg, akikről okkal feltélezhettük, hogy járatosak a települési kapcsolatrendszerekkel összefüggő fogalomrendszer értelmezésében. Egyben rendelkeznek a témánk szempontjából megfelelő információkkal. Pozíciójukból adódóan nem mellékes az álláspontjuk, véleményük megismerése, hiszen szemléletüknek jelentős befolyása lehet a helyi kapcsolatrendszerek széles körének alakulására.

\section{Módszer}

2013-2014 fordulóján városi polgármesterekkel folytattunk strukturált, kérdőíves interjúkat személyes megkereséssel, kérdezőbiztosok útján. A felmérést a Medián Közvélemény- és Piackutató Intézet végezte. A kérdőív alapváltozatát a kutatási koncepcióhoz igazodva a projektteam készítette el. A fővárosi kerületekkel együtt 369 polgármester alkotta városi sokaságból 198-at kértünk föl interjúra. Közülük 109 válaszadás volt sikeres, ami 55\%-os arányt jelent. Az így keletkezett minta földrajzi értelemben, a jellemző település-nagyságcsoportokat is tekintve reprezentatívnak tekinthető. A válaszoló polgármestereknek értékes közreműködésükért köszönettel tartozunk.

A gazdasági kapcsolati formák alakulását az ő állításaik alapján igyekszünk követni. Az adatok egy további része a kormányzás városi társadalmi kapcsolataira vonatkozik. Ebben a körben összehasonlító számokat is hozzá tudunk rendelni a jellemzéshez, kontrollcsoportot is alkalmaztunk a járási hivatalvezetők személyében. A módszertan e része a későbbiekben olvasható. Az összehasonlítás báziskutatásának leírását a Melléklet tartalmazza.

\section{Gazdasági kapcsolati formák}

Az előbbiekben kifejtett elméleti keretek alapján az átfogó modern városi hálózatosság jellemző gazdasági szervezési típusaiként a városi gazdaságfejlesztés egyes módjait, az újabb térszerveződési léptékalakzatokat és az önkormányzati felelős társaságirányítású vállalatokat azonosítottuk. Empirikusan ezekhez tételesen meghatározott formák rendelhetők, amelyek létét már mérni tudjuk, az alábbiak szerint.

- A helyi gazdaságfejlesztéshez kapcsolhatók a klaszterek, azaz a termelésiszolgáltatási kapcsolatban álló vállalkozások területi vagy tevékenységi együttmüködései.

- Az újabb léptékformákként egyrészt a helyi innovációs központokat nevesítjük, amelyek egyben a korszerü húzóágazatok (informatika, elektro- 
nika, nanotechnológia stb.) összekötő pontjai, térbeli és virtuális kapcsolati hálók nélkül ezek léte, prosperálása elképzelhetetlen lenne. Másrészt az intermodális központokat emeljük ki, amelyek a különböző közlekedési formák közötti átszállást biztosító kapcsolati pontok, és amelyekre rátelepülnek a különböző cégek és szolgáltatások. Harmadrészt a tudásközpontokra érdemes figyelni, vagyis a helyi gazdasági kapcsolatrendszerbe illeszkedő egyetemi, kutatási vagy kulturális centrumokra. E központokat, az európai uniós csatlakozással összefüggésben, jó ideje jelentős projektalapú támogatásokban részesítik hazánkban is.

- A felelős társaságirányítás önkormányzati formái azok a vállalatok, amelyek többségi helyi vagy központi kormányzati tulajdonban vannak és közszolgáltatásokat nyújtanak. Átfogóan, gyüjtőnévvel ezeket közvállalatoknak nevezzük.

A polgármesterek válaszai alapján a települések több mint a felében (53\%) van legalább egy, a fentiekben meghatározott és a felmérésben szereplő új típusú gazdasági szervezet (1. táblázat). A legtöbb településen (46 százalék) közvállalat múködik, 21\%-ukban több is, a legritkábban (12\%) pedig helyi innovációs központok létéről számoltak be. Klaszter a városok közel egynegyedében működik, a többségükben egy.

A városokban müködő új típusú gazdasági szervezetek közül minden második kistérségi, minden negyedik-ötödik regionális szervezet. Viszont ritka a határokon átnyúló szervezet. Jellemző, hogy nem a közigazgatási területbeosztási egységek dominálnak, hanem a rugalmasabb térségi formák. A hálózatosság sajátossága éppen ez. Összességében megállapítható, hogy a hálózatosság érdemben jelen van a magyar városok körében. Látva a térségi kiterjedést, ez egyben a központi helyhez kötődő más települések érintettségére is utal.

A klaszterek relatív többsége a hagyományos ipari termelésben müködik, de számottevő az oktatáshoz, kutatáshoz, innovációhoz, a kultúrához, művészethez, sporthoz, valamint a mezőgazdasághoz, illetve élelmiszeriparhoz kapcsolódó klaszterek száma is (2. táblázat).

1. táblázat: Új típusú gazdasági szervezetek a vizsgált városokban (\%) New types of economic organisations in the studied cities (\%)

\begin{tabular}{lccccc}
\hline & Klaszter & $\begin{array}{c}\text { Helyi innovációs } \\
\text { központ }\end{array}$ & $\begin{array}{c}\text { Intermodális } \\
\text { központ }\end{array}$ & Tudásközpont & Közvállalat \\
\hline Nincs & 76 & 88 & 85 & 78 & 55 \\
Van & 24 & 12 & 15 & 22 & 46 \\
\hline Ebböl: & & & & & \\
1 & 14 & 11 & 7 & 13 & 24 \\
2 & 4 & 0 & 6 & 4 & 8 \\
3 & 5 & 1 & 1 & 1 & 7 \\
4 & 0 & 0 & 1 & 2 & 4 \\
5 vagy több & 1 & 0 & 0 & 2 & 3 \\
\hline
\end{tabular}


2. táblázat: A klaszterek profilja (a sorok \%-ában)

The profile of clusters (in \% of row totals)

\begin{tabular}{lrcc}
\hline \multicolumn{1}{c}{ Profil } & Van & Nincs & Nem tudja \\
\hline Hagyományos ipari termelés & 38 & 57 & 5 \\
Elektronika, számítástechnika & 8 & 87 & 5 \\
Környezetgazdálkodás & 8 & 87 & 5 \\
Infrastrukturális szolgáltatások & 13 & 82 & 5 \\
Mezőgazdaság, élelmiszeripar & 16 & 79 & 5 \\
Oktatás, kutatás, innováció & 18 & 76 & 5 \\
Kultúra, művészet, sport & 16 & 79 & 5 \\
\hline
\end{tabular}

A termelési vagy szolgáltatási klaszternek az önkormányzat, illetve az állam nem feltétlenül résztvevője. Más kérdés, hogy a kialakulást a helyi vagy központi kormányzat gazdasági vagy fejlesztési politikájával ösztönözheti. Ez azonban nem szükségszerű, és nem is feltétlenül szükséges. A városi önkormányzat vagy valamelyik intézménye adataink szerint kisebb részben tagja a klaszternek. Nagyok az ágazati különbségek ebben az összefüggésben: az önkormányzat szerepvállalása a kultúra, művészet, sport területén a leginkább jellemző, és a mezőgazdaságban, élelmiszeriparban a legkevésbé. Ez azt jelenti, hogy a kifejezetten helyi feladatkörökben nagyobb a szerepvállalás gyakorisága.

A tudásközpontok relatív többsége az oktatás és a kultúra területén müködik. A legkevésbé a számítástechnikára, informatikára jellemző ez a szervezeti forma (3. táblázat).

Az önkormányzat (tagsági) részvétele a tudásközpontokban sokkal kevésbé jellemző, mint a klaszterekben, mert jellemzően egyetemek és más felsőoktatási intézmények köré szerveződnek az ilyen kapcsolatok. Csupán a kultúra, művészet, sport területén müködő tudásközpontokban vannak többségben azok, amelyeknek tagja a városi önkormányzat, közvetlenül vagy valamelyik intézménye révén.

Tudnunk kell azonban, hogy a felsőoktatási tudásközpontoknak rendkívül nagy hatása van a szükebb települési környezetre. A fejlődésre, ellátottságra, munkaerőhelyzetre, ingatlanárakra gyakorolt befolyás meghatározó.

3. táblázat: A tudásközpontok profilja (a sorok \%-ában)

Profiles of knowledge centres (in \% of row totals)

\begin{tabular}{lrcc}
\hline \multicolumn{1}{c}{ Profil } & Van & Nincs & Nem tudja \\
\hline Hagyományos ipari termelés & 14 & 74 & 11 \\
Elektronika, számítástechnika & 6 & 82 & 12 \\
Környezetgazdálkodás & 17 & 71 & 11 \\
Infrastrukturális szolgáltatások & 17 & 71 & 11 \\
Mezőgazdaság, élelmiszeripar & 17 & 71 & 11 \\
Oktatás, kutatás, innováció & 33 & 56 & 11 \\
Kultúra, művészet, sport & 26 & 63 & 11 \\
\hline
\end{tabular}


Ami az új típusú formák dinamikáját illeti, a polgármesterek válaszai szerint a városok 30\%-a tervezi, hogy részt vesz (újabb) klaszterben, intermodális központ szervezésében, tudásközpont kialakításában vagy közvállalat létrehozásában. A jövőbeni részvételt többen tervezik azokban a városokban, amelyekben működik már ilyen szervezet, mint azokban, amelyekben egyelőre nem.

Polgármester-válaszadóinkat az európai uniós szerepvállalásról is kérdeztük. Válaszaik szerint a szervezetek többségének létrejöttét támogatta az Európai Unió. A támogatás különösen nagy szerepet játszott a klaszterek és a helyi innovációs központok létrejöttében, de az intermodális központok és a közvállalatok csupán kisebb részének alapítására volt közvetlen hatással. Először is azért, mert az önkormányzati gazdasági társaságok sajátos tulajdonosi irányítási rendszere valójában nem európai uniós támogatási célpont. Esetünkben azonban ennél többről van szó. 2010 után jelentősen megerősödött a korábbi évek holdingalakítási tendenciája, majd a közművállalatok önkormányzati tulajdonba való visszavétele került előtérbe. Másrészt Magyarországon a közvállalattá alakításnak olyan formája vált elterjedtté, amely előbb az önkormányzati tulajdonba való visszavételt erősítette, majd az állami tulajdonhányadot emelte meg, olyannyira, hogy szinte államosításról beszélhetünk. Ez a folyamat nem kisajátítás volt, de nem nélkülözte a „gazdaságon kívüli kényszer” elemeit.

Ebben az értelemben e folyamatot csak kezdeti stádiumában lehetett maradéktalanul a hálózatosodás trendjébe illeszteni. Mégpedig addig a pontig, ameddig a holding a korábbi privatizációk után is önkormányzati tulajdonban maradt, ami a közmüvállalatok átalakítására volt inkább jellemző. Nagyjából ez az irány 2006-tól 2011 végéig tartott. 2012 elejétől azonban, törvényi változások hatására, egyre gyakrabban közhatalmi eszközökkel avatkoztak be a közüzemi szektor tulajdonosi irányításába. Ezért ettől fogva a közvállalati kör egyre kevésbé terepe a klasszikus hálózatosodásnak, sokkal inkább az állami irányítás hangsúlyos és a kormánypolitika erőterében álló eszközévé vált.

Az állami, azon belül is a központi kormányzati beavatkozások befolyásolják a többi hálózatossá váló formát is - azonban korántsem ekkora erővel. A klaszterek, az innovációs, az intermodális és a klasszikus tudásközpontok müködésére gyakorolt hatás 2014-ig korántsem ennyire elementáris. Azaz kétféle - nem a szigorúan vett területbeosztáson alapuló - struktúra él egymás mellett a 2010-es évek közepének Magyarországán: a modern városi hálózatosság és az állami irányítás kibővített és elaprózott hierarchiája, amely a területi viszonyokban a korábbinál mélyebbre hatol. Ezt a „bőr alá szúrást” mutatja a közvállalati súly növekedése, burjánzása a hálózati formákhoz viszonyítva.

Az alapvető összefüggést az 1. ábra sematikusan ábrázolja.

Nem egyszerüen az állami szerepek léte a szokatlan, a hálózatosodás minden formája új közösségi formákat és eszközöket feltételez, beleértve a hatalmi szerveket is. Rendszeresen előfordul például, hogy projektekkel ösztönzik a húzóágazatok megtelepedését, a nem hagyományos infrastruktúra fejlesztését. A legkülönbözőbb kormányzati szintek közötti (elsősorban pénzügyi) kapcsola- 
1. ábra: Két rendszer Magyarországon 2014-ben

Two systems in Hungary, 2014

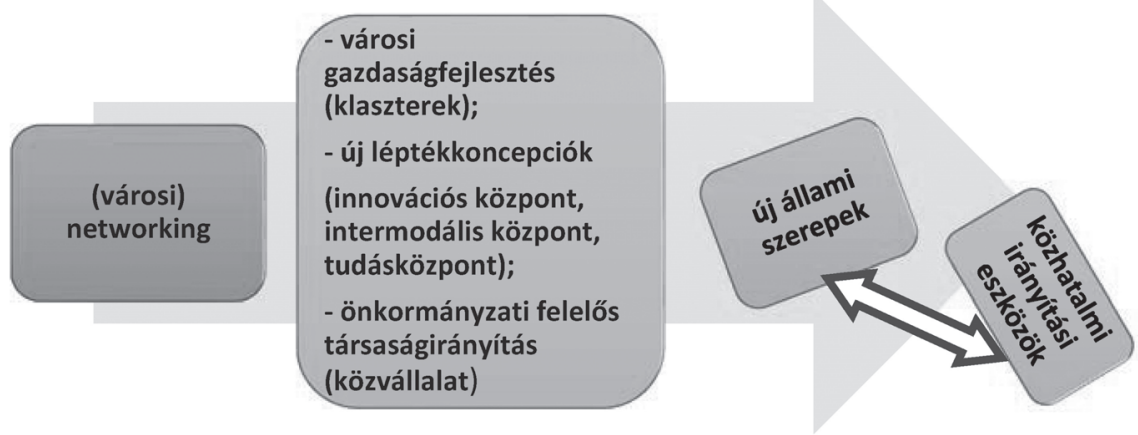

tokban jelennek meg az ösztönzés eszközei. Az Európai Unió forrásainak igénybevételére konkrét interjúkérdésünk is irányult, a válaszokból kiderült, hogy ez más, mint a közvetlen államigazgatási irányítási befolyás.

Az eltérésen túl lényeges a kétféle strukturáltság: a hálózatos és az állami irányítási struktúrák egymás mellett élése, mivel ezek hatásai a helyi politika alakítására, illetve annak tartalmára nézve igen nagyok. A közvállalatok szélsőséges állami támogatásához képest az intermodális központok támogatásban részesítésének „finomabb” módja jól árnyalja az összképet. A közlekedési beruházások közösségi forrásigénye mindig is jellemző volt. A hagyományos (kormányzati) támogatások igen jelentősek, de keverednek az uniós forrásokkal, mutatva ezzel a két módszer praktikus összebékíthetőségének reális lehetőségét is. Mindez kihat a városvezetés helyi politikai stratégiájára, közösségi kapcsolatrendszereire.

Megkockáztatható az a hipotézis, hogy a feladatrendszer - területi kötöttségeket háttérbe szorító - hálózatosodása hatással van a társadalmi kapcsolatrendszerek alakulására. A hazai sajátosságoknak - ami az állami irányítás erősödését és közvetlenné válását illeti - pedig tükröződniük kell a hagyományos demokráciákkal mint viszonyítási pontokkal való összehasonlításban.

\section{Társadalmi kapcsolati formák}

A polgármesteri interjúkban vizsgáltuk a városvezetés társadalmi kapcsolatait. A jelenlegi magyar közösségi kapcsolatrendszer sajátosságai akkor válnak nyilvánvalóvá, ha viszonyítási pontokat jelölünk ki. A magyar vizsgálatok egy részét össze tudjuk vetni két európai - a német és a francia - modell adataival. Rendelkezünk ugyanis egy olyan elemzéssel (a mellékletben e kutatás leírása is olvasható), amely a helyi képviseleti demokráciák sajátosságait - szintén empirikus felvétel alapján - írja le. Heinelt, Kerrouche és Egner (2006) városi polgármesterek (és igazgatási vezetők) megkérdezésén és az eredmények statisztikai 
feldolgozásán alapul. Az önkormányzathoz képest az önkormányzás rugalmasabb formáit vizsgálták az ezredforduló utáni helyi igazgatási viszonyok között. Sok tekintetben az örökölt tradíciókra és az újabb változások hatásaira vezették vissza a kimutatott jelenségeket a két országban. A társadalmi és közösségi kapcsolatokra vonatkozó magyar kutatásunk adatait össze tudjuk hasonlítani Francia- és Németország adataival.

Az érdekek becsatornázásáról Magyarországon a polgármesterek azzal értenek a leginkább egyet, hogy lehetőséget kell biztosítani az embereknek a közvetlen véleménynyilvánításra a testület fontos döntései előtt. Valamivel kevésbé elfogadott az a nézet, hogy a lakosság közügyekben való részvételéhez elegendő a nyilvánosság biztosítása, illetve az, hogy a városi vezetőknek maguknak kell meghozni a fontos döntéseket. Annak megítélésében azonban, hogy az önkormányzati képviselők az emberek megkérdezése nélkül is megfelelően közvetítik az emberek akaratát, enyhén túlsúlyban vannak az elutasító vélemények. A 4. táblázatban ugyanezekben a kérdésekben a német és a francia polgármesterek véleménye is olvasható.

Az állampolgárok akaratának megjelenítési eszközei a döntéshozatal folyamatában különbözőek. Feltűnő az adatok alapján, hogy a német és a francia polgármesterek véleményei „kompaktabbak”, ők ugyanis a polgármesterek felhatalmazottsága oldaláról közelítenek. Emiatt a városvezetői döntés és felelősségvállalás követelménye egyaránt az első helyen szerepel. A következő szempont eltérése Franciaországban a képviseleti demokrácia, míg Németországban inkább a konzultatív vagy konszenzusos modell felé mutat. Közpolitikai értelemben az önkormányzattal szemben (vagy amellett) az önkormányzás értékeit részesítik inkább előnyben. A magyar rendszerben a vezetői (ön-)elfogadottság egyértelműen alacsonyabb, míg a felhatalmazottság tárgyában meglehetősen eltérő a megítélés a másik két országtól. Miközben inkább elutasítóak a választott képviselők érdekkifejezésének megalapozottságáról, a közvetlen véleménynyilvánítás „mögé bújnának” - ami inkább elbizonytalanodást, mint-

4. táblázat: Demokratikus követelmények érvényesülése a polgármesterek szerint Participative elements in the city development according to mayors surveyed

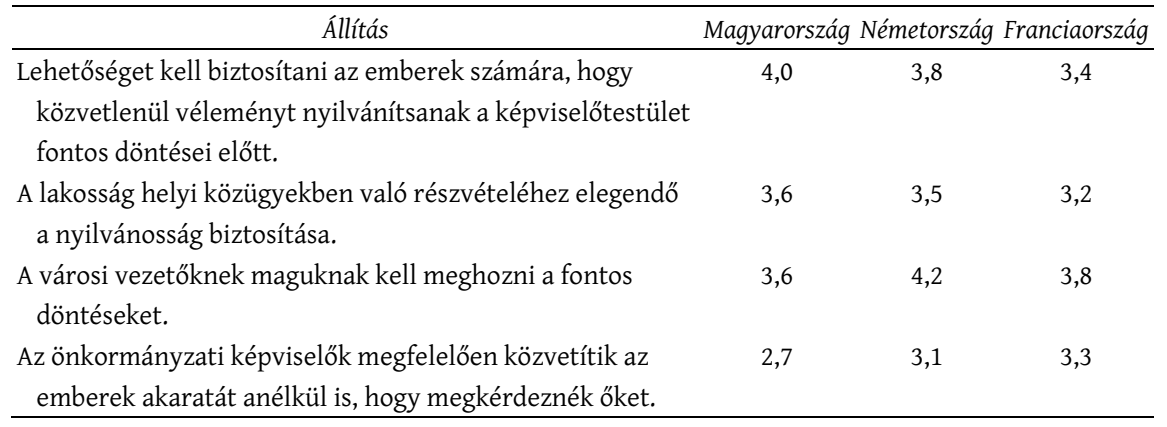

Megjegyzés: ötfokú skála átlagai, 5= teljesen egyetért, 1=egyáltalán nem ért egyet. 
5. táblázat: A kapcsolat gyakorisága a polgármesterek és egyes szervezetek között (\%) How often do mayors and particular organizations meet? (\%)

\begin{tabular}{lrrrrr}
\hline \multicolumn{1}{c}{ Szereplók } & Soha & Ritkábban & Havonta & Hetente & Naponta \\
\hline Vállalkozók & 0 & 5 & 19 & 39 & 37 \\
Szakszervezetek & 25 & 58 & 11 & 6 & 0 \\
Közhasznú szervezetek képviselői & 0 & 16 & 42 & 27 & 16 \\
Ttársadalmi szervezetek képviselői & 0 & 8 & 36 & 40 & 16 \\
Állampolgárok & 0 & 2 & 6 & 11 & 82 \\
A járási hivatal vezetője & 1 & 6 & 14 & 62 & 17 \\
A térségbe tartozó más helyi & 0 & 5 & 22 & 58 & 16 \\
$\quad$ önkormányzat polgármestere & & & & & \\
$\quad$ Térségen kívüli magyarországi helyi & 1 & 33 & 42 & 19 & 5 \\
$\quad$ önkormányzat polgármestere & & & & & \\
A kormányhivatal vezetője & 8 & 31 & 43 & 16 & 3 \\
A kormányhivatal más munkatársai & 2 & 31 & 40 & 26 & 2 \\
Minisztérium, országos szerv & 4 & 32 & 31 & 28 & 5 \\
$\quad$ munkatársai & & & & & \\
\hline
\end{tabular}

sem erős elkötelezettséget sugall. A kormányzat és a kormányzás struktúrái iránt a bizalom viszonylag alacsony.

Lássuk, hogy a konkrét kapcsolati formák jelenléte igazolja-e ezt az általános értékelést! A magyar polgármesterek (5. táblázat) a leginkább intenzív kapcsolatot az „állampolgárokkal” tartják: 82\%-uk válaszolta azt, hogy naponta személyesen kommunikál ezzel a körrel. Másokkal kevésbé intenzív a kapcsolattartás, de a városvezetők többsége legalább hetenként találkozik a térségbe tartozó másik helyi önkormányzat és járási hivatal vezetőjével. A városvezetésnek a szakszervezetekkel a legkevésbé intenzív a kapcsolata.

A járási hivatalok vezetőinek Magyarországon (nem reprezentatív minta szerint) kevésbé intenzív a kapcsolata a környezetével, mint a polgármestereknek. Körükben is az állampolgárokkal tartják leggyakrabban a kapcsolatot, ezen kívül a kormányhivatal munkatársaival, illetve a járásszékhely város polgármesterével találkoznak legalább hetenként.

A polgármesterek szerint az állampolgároknak van a legnagyobb befolyásuk a városi önkormányzat döntéseire, a második legbefolyásosabb csoport a vállalkozóké, a harmadik és a negyedik csoport a társadalmi szervezetek képviselöié, és a minisztérium, illetve más országos szerv munkatársaié. A válaszok megoszlásából az igazgatási és a rugalmasabb kormányzási kapcsolatok együttes jelenlétére következtethetünk.

A közérdek megjelenítésének különböző demokráciatípusú módjai közül Magyarországon a közhasznú szervezetek öntevékenységének megítélése a legkedvezőbb. A közvetlen demokráciát megjelenítő helyi népszavazásé a legkevésbé kedvezö, de a felmérésben szereplő hat eszköz mindegyikében az elfogadás az erősebb. Három kérdésben van összehasonlító adatunk: a partnerség, a pártképviselet és a közvetlen demokrácia formái nagyjából azonos szin- 
6. táblázat: A közérdek megjelenítését szolgáló eszközök, szervezetek, fórumok megítélése Statements on representation of public interests

\begin{tabular}{|c|c|c|c|}
\hline Állítás & $\begin{array}{c}\text { Magyar } \\
\text { polgármesterek }\end{array}$ & $\begin{array}{c}\text { Német } \\
\text { polgármesterek }\end{array}$ & $\begin{array}{c}\text { Francia } \\
\text { polgármesterek }\end{array}$ \\
\hline $\begin{array}{l}\text { A közhasznú szervezetek a helyi közösségek } \\
\text { akaratát is kifejezik. }\end{array}$ & 73 & & \\
\hline $\begin{array}{l}\text { A közösségi feladatok ellátásában a köz- és a } \\
\text { magánszektor közötti üzleti együttműködési } \\
\text { formák ugyanolyan fontosak, mint az } \\
\text { önkormányzati képviseleti rendszer. }\end{array}$ & 70 & 66 & 64 \\
\hline $\begin{array}{l}\text { Az egyházaknak legyen véleménye a közérdekű } \\
\text { helyi kérdésekben. }\end{array}$ & 67 & & \\
\hline $\begin{array}{l}\text { A kamarák a szakmai közérdek kifejezői helyi } \\
\text { kérdésekben. }\end{array}$ & 60 & & \\
\hline $\begin{array}{l}\text { A pártok az állampolgári részvétel legmegfelelőbb } \\
\text { megjelenítői a közéletben. }\end{array}$ & 63 & 70 & 62 \\
\hline $\begin{array}{l}\text { A helyi népszavazás magas színvonalú társadalmi } \\
\text { vitát gerjeszt. }\end{array}$ & 57 & 60 & 58 \\
\hline
\end{tabular}

Megjegyzés: 0-100 skálára konvertált átlagok, ahol 0=egyáltalán nem ért egyet, 100=tökéletesen egyetért.

ten elfogadottak a három országban. A magyar átlagértékek közötti szórás nagyobb, mint a francia és német modellekben, ami a közérdek kifejeződésének formáit illetően az eltérő (egymással nem feltétlenül konzisztens) értékrendek egymás mellett élésére utal a társadalmi kapcsolatrendszerekben (6. táblázat).

A magyar polgármesterek az állampolgári akarat megismerésének legmegfelelőbb formájaként a lakossági fórumot és a képviselők, illetve a polgármesteri hivatal által gyüjtött véleményeket ítélik. Érdekes, hogy minél formalizáltabb a megoldás, azaz minél inkább van kötelező döntési vonzata, annál kevésbé tartják alkalmasnak a közösségi akarat tényleges megjelenítésére. $\mathrm{E}$ fordított arányosság alól csak az online fórumok kivételek, amelyeket kötetlen formájuk ellenére sem értékelnek pozitívan a polgármesterek. A kormányzás erősebb hatású eljárási megoldásai tehát nem nagyon kedveltek.

Összehasonlítva a másik két országgal, a német eredmények a részvételi demokrácia képét rajzolják ki a közvetlen beleszólás formáinak (lakossági fórum, közmeghallgatás) magasra vagy relatíve magasra (helyi népszavazás) értékelésével. A francia állapotok viszont a képviseleti demokrácia modelljére vallanak a követlen képviseleti formák mellett a választott testületi tagok tevékenységének elismertsége révén. A magyar gyakorlatban a lakossági részvételi formák elismertsége sem abszolút értelemben, sem relatíve nem magas, viszont a képviseleti intézmények sem látszanak túl megbízhatónak az ebben a kérdésben autentikusnak tekinthető polgármesterek válaszai alapján (7. táblázat).

A társadalmi kapcsolatokban a formalizált megoldások mellett rugalmasabb közösségi érdekkifejezési technikák jelenléte, működése Magyarországon korlátozott. A belső vagy a közigazgatási határokon átívelő hálózatosság fejlő- 
7. táblázat: Az állampolgári akarat megjelenítési eszközeinek megítélése a polgármesterek szerint Effectiveness of fora to represent citizens' opinions according to mayors

\begin{tabular}{|c|c|c|c|}
\hline Eszköz & Magyarország & Németország & Franciaország \\
\hline Lakossági fórum & 1,64 & 1,93 & 1,90 \\
\hline $\begin{array}{l}\text { Önkormányzati képviselők } \\
\text { által gyüjtött lakossági } \\
\text { vélemények }\end{array}$ & 1,62 & 1,18 & 1,72 \\
\hline $\begin{array}{l}\text { Polgármesteri hivatal által } \\
\text { gyűjtött lakossági } \\
\text { vélemények }\end{array}$ & 1,59 & 1,37 & 1,55 \\
\hline Közmeghallgatás & 1,41 & 1,72 & 1,75 \\
\hline Helyi népszavazás & 1,27 & 1,37 & 0,88 \\
\hline $\begin{array}{l}\text { Online fórumok, közösségi } \\
\text { oldalak }\end{array}$ & 0,96 & & \\
\hline $\begin{array}{l}\text { Pártok által gyűjtött } \\
\text { lakossági vélemények, } \\
\text { aláírásgyűjtés }\end{array}$ & 0,91 & 1,02 & 0,82 \\
\hline
\end{tabular}

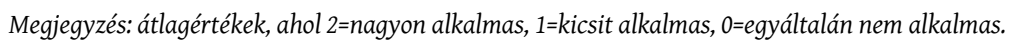

dése jelenleg mintha megingott volna. A kettősség a képviseleti megoldásokban nem elég markáns, inkább a közepesen következetes megoldások nyernek teret. Ebben a vonatkozásban a gazdasági kapcsolati formák megkettőződése erőteljesebbnek mutatkozik.

Összefoglalva, az önkormányzatok közjogi formájával mindig konkurálnak a hálózatosság gazdasági és társadalmi alakzatai. Erre mutatnak rá a részvételi, illetve a képviseleti modellek empirikus tapasztalatai. Ugyanez a versengés akkor is megmutatkozik, ha a közjogi forma kifejezetten az államigazgatási megoldásokat állítja előtérbe. Ebben az esetben azonban a gazdasági hálózatok jobban láthatóvá és ezáltal relatíve jelentősebbé válnak.

\section{Köszönetnyilvánítás}

A tanulmány a szerző által vezetett OTKA K 101147 számú, A városi kormányzás közepes városokban és várostérségekben című kutatási projekt keretében készült.

\section{Irodalom}

Bevir, M. (2008): Key concepts in governance. University of California, Berkeley

Castells, M. (ed.) (2004): The network society: A cross-cultural perspective. Edward Elgar, Cheltenham http://doi.org/4j7 
Collinge, C., Srbljanin, A. (2003): A network paradigm for urban governance? In: Hambleton, R., Saritch, H. V., Stewart, M. (eds.): Globalism and local democracy: Challenge and change in Europe and North America. Palgrave Macmillan, Houndmills, 169-184.

Dietrich, M. (2011): Corporate governance in Germany. Economic Studies and Analyses / Acta VSFS, 2., 148-165.

ESPON Scientific Report II. (2006): Applied territorial research: Building a scientific platform for competitveness and cohesion. Luxemburg. www.espon.eu

Faragó L. (1994): Regionális gazdaságfejlesztés „keresletoldali” stratégiák segítségével. Comitatus, 12., 60-63.

German corporate governance code. Government Commission, 2010. http://www.corporate-governance-code.de/eng/kodex/6.html (a 2010. évi utolsó módosításokkal egységes szöveg, - letöltés: 2012. február 27.)

Grossi, G. (2007): Governance of public-private corporations in the provision of local utilities in the Italian case. International Public Management Review, 1., 130-151.

Grossi, G., Reichard, C. (2008): Municipal corporatization in Germany and Italy. Public Management Review, 5., 597-617. http://doi.org/cg25h4

Grossi, G., Thomasson, A. (2011): Jointly owned companies as instruments of local government: comparative evidence from the Swedish and Italian water sectors. Policy Studies, 3., 277-289. http://doi.org/fswc54

Hakansson, H. (2010): Határtalan hálózatok. Az üzleti kapcsolatok menedzsmentjének új szemlélete. Aliena Kiadó, Budapest

Heinelt, H., Kerrouche, É., Egner, B. (2006): From government to governance at the local level: Some considerations based on data surveys with mayors and chief exective officers. In: HoffmanMartinot, V., Wollmann, H. (eds.): State and local government reforms in France and Germany: Divergence and convergence. VS Verlag für Sozialwissenschaften, Wiesbaden, 207-230. http://doi.org/cmctkp

Herrigel, G. (2007): A new wave in the history of corporate governance. Enterprise \& Society, 3., 475-488. http://doi.org/ft5373

Hoffmann-Martinot, V., Wollmann, H. (2006): State and local government reforms in France and Germany: Divergence and convergence. VS Verlag für Sozialwissenschaften, Wiesbaden http://doi.org/fw5sxg

Homan, J., Howl, D., Tosics, I. (2007): URBACT METROGOV Final Report. URBACT, Birmingham

Horváth M. T., Józsa Z., Hoffman I. (2013): Újraszabva. A városi kormányzás szövete a kontinensen. In: Horváth M. T. (szerk.): Jelenségek. A városi kormányzás köréból. Dialóg Campus, Budapest, 9-42.

Howlett, M. (2011): Designing public policies. Routledge, London

John, P. (2001): Local governance in Western Europe. SAGE, London

Józsa Z. (2008): Trends and developments: Local governments in Western Europe. International Journal of Public Administration, 2., 12-14.

Lengyel I., Deák Sz. (2002): Klaszter: a helyi gazdaságfejlesztés egyik sikeres eszköze. In: Buzás N., Lengyel I. (szerk.): Ipari parkok fejlődési lehetőségei: regionális gazdaságfejlesztés, innovációs folyamatok és klaszterek. SZTE GTK, Szeged, 125-153.

Lorrain, D. (2005): Urban capitalisms: European models in competition. International Journal of Urban and Regional Research, 2., 231-267. http://doi.org/dgks2s

Marcussen, M., Torfing, J. (2007): Democratic network governance in Europe. Palgrave Macmillan, Basingstoke

METREX (2005): The network of European regions and areas. www.eurometrex.org

Mezei C. (2004): Önkormányzati gazdaságfejlesztési gyakorlat a hazai településeken. In: Pálné Kovács I. (szerk): Versenyképesség és igazgatás. (Tanulmányok a versenyképesség igazgatási feltételeiről). MTA RKK, Pécs, 181-265.

Mezei C. (2007): A helyi gazdaságfejlesztés elméleti hátteréről. In: Horváth M. T. (szerk.): Piacok a fótéren. Helyi kormányzás és szolgáltatásszervezés. KSzK, Budapest, 121-159.

Pálné Kovács I. (vendégszerk.) (2008a): Városi kormányzás. Tér és Társadalom, 1.

Pálné Kovács I. (2008): Az új várospolitika kormányzási filozófiája. Tér és Társadalom, 1., 45-57.

Péteri G. (2007): Nagyobb felelősség, átalakuló feladatok, új szerepek. Helyi közszolgáltatások és döntéshozatal változása a polgármesterek véleménye alapján (1991-2006). In: Horváth M. T. 
(szerk.): Piacok a fótéren. Helyi kormányzás és szolgáltatásszervezés. KSzK, Budapest, 19-68.

Pierre, J., Peters, B. G. (2000): Governance, politics and the state. Macmillan, Houndmills

Somlyódyné Pfeil E. (2008): A városi térségek a közigazgatási struktúra és a „governance” keresztmetszetében. Tér és Társadalom, 1., 24-43.

Somlyódyné Pfeil E. (2011): Az agglomerációk jelentőségének változása az államszervezés és a városi kormányzás szempontjából. Tér és Társadalom, 3., 27-59.

Somlyódyné Pfeil E. (2014): Az állam megváltozott szerepe és a városfejlesztés viszonya. Tér és Társadalom, 2., 31-44.

Sorensen, E., Torfing, J. (2007): Theories of democratic network governance. Palgrave Macmillan, Basingstoke

Stoker, G. (2006): Public value management. A new narrative for networked governance? American Review of Public Administration, 1., 41-47. http://doi.org/chg6wd

Stoker, G. (2011): Was local governance such a good idea? A global comparative perspective. Public Administration, 1., 15-31. http://doi.org/fjtz3q

Sullivan, H., Skeltcher, C. (2002): Working accross boundaries. Palgrave, Basingstoke

Stumpf I. (2008): A „szuperkapitalizmus” válsága avagy erős állam és társadalmi kiegyezés. Közigazgatási Szemle, 3-4., 16-23.

Tosics I. (2008): Nagyvárosi kormányzás: A város és környéke együttmüködése. Külföldi példák és a hazai relevancia. Tér és Társadalom, 1., 3-25.

URBACT II: www.urbact.eu

Wollman, H., Marcou, G. (eds.) (2010): The provision of public service in Europe: Between state, local government and market. Edward Elgar, Cheltenham http://doi.org/4j8

Ziegler, J. N. (2000): Corporate governance and politics of property rights in Germany. Politics \& Society, 2., 195-221. http://doi.org/d6dvp7

\section{Melléklet}

\section{A városi kormányzás társadalmi kapcsolatainak vizsgálatához használt referenciakutatás jellemzői}

A kormányzás „puhább” formái közül a közösségi-társadalmi kapcsolatok vizsgálatához referenciaként Heinelt, Kerrouche, Egner publikációját (2006) használtuk. E tanulmány egy 2003-ban végzett kérdőíves felmérés németországi és franciaországi eredményeit hasonlítja össze a magyar állapottal. Témája a kormányzattól a kormányzás felé mutató formák keresése és értékelése helyi szinten a polgármesterek és az önkormányzatok hivatali vezetőinek megkérdezésével.

A felmérés alapsokaságát a 10000 lakosúnál nagyobb magyar városok alkották. Németországban 637 (41 \%), Franciaországban 188 (21 \%) válasz érkezett, a minták egyes település-nagyságcsoportokat aránytalanul képviselnek, Németországban felül-, Franciaországban alulreprezentáltak.

A kutatás végkövetkeztetése az volt, hogy a német városok inkább a konszenzusos demokrácia típusát jelenítik meg, míg a franciák a képviseleti, többségi elvüt. Ennek megfelelően az interaktív politikaalkotás - amely a kevésbé formális kormányzási modell alapja - Németországra jellemző. Az igazgatási modelleken túl a vizsgálat legfontosabb tanulsága az egyes alapmintákhoz való 
hűség, tehát az egyik vagy másik demokráciafelfogás következetes követésének lehetségessége és ténylegessége.

A magyar felmérést e projekttől függetlenül, követő módon végeztük. 2013-ban kérdeztük meg a városi polgármestereket. Alapsokaságnak az összes városi polgármestert tekintettük, beleértve a fővárosi kerületeket is. A 369 elemből elsődlegesen 198 került a mintába. A megkeresett polgármesterek közül a személyes interjúra 109-en vállalkoztak. A teljes sokaság 30\%-a alkotja a csökkentett mintát, ami összességében megfelelő. Földrajzilag és településnagyságcsoportokat tekintve a minta reprezentatívnak tekinthetö. Jelen tanulmányban nem válogattuk ki a tízezer lakosúnál nagyobb városokat, mert ez az elemszám csökkenését eredményezte volna. Az összehasonlítást az azonos kérdések feltevése és a feldolgozás azonos módszertana tette lehetővé.

Milyen jelentősége van annak, hogy a hazai adatfelvételt 10 évvel később végeztük? Az időtényezőnek fontos szerepe van. Feltehető, hogy a kormányzati politikaalkotás jellemzői Magyarországon is különbözőek lettek volna közvetlenül az ezredforduló után. A vizsgálatok időbeli eltérése azonban nem volt akadálya a tudományos következtetések levonásának, amelyek szerint Németországot 2003ban a városi konszenzusos demokrácia kormányzási modelljének tekintették, Franciaországot pedig a képviseleti demokrácia kormányzási alakzatának. A konszenzusos, illetve a többségi modellekhez képest relatív elmozdulás mutatható ki Magyarországon. 